\title{
JUURNAL.RU
}

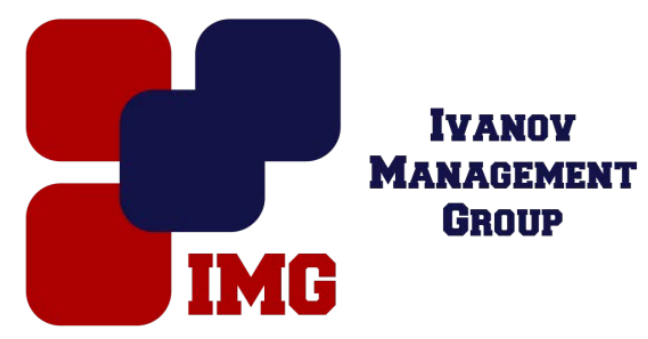

\author{
Солозобова Н.С., Костин К.Б., Шумилин А.И., Пичхидзе С.Я. \\ СГТУ им. Ю. А. Гагарина \\ Саратов, Россия
}

doi: 10.18411/lj-31-03-2017-2-13

idsp 000001:lj-31-03-2017-2-13

\section{Термическое нанесение меди и алюминия на фторлон-4}

Термическое нанесение является одной из современных технологий нанесения покрытий. Основные преимущества нанесения термическим способом заключаются в получении покрытия из медной/алюминиевой пленок толщиной от сотых долей мкм с высокой адгезией к подложке без газовой среды [1...4].

Цель работы заключалась в анализе морфологии поверхности ткани фторлон-4 и получении спектров методом РЭМ/ЭДРА.
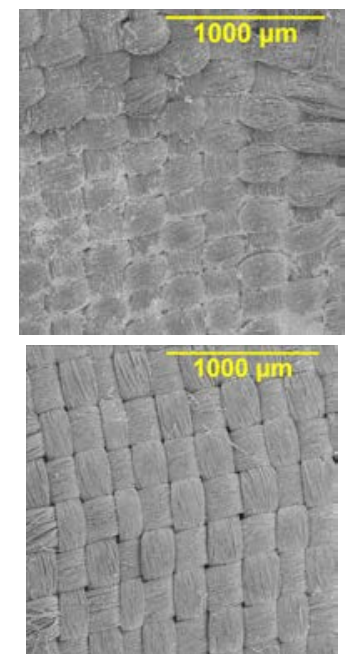
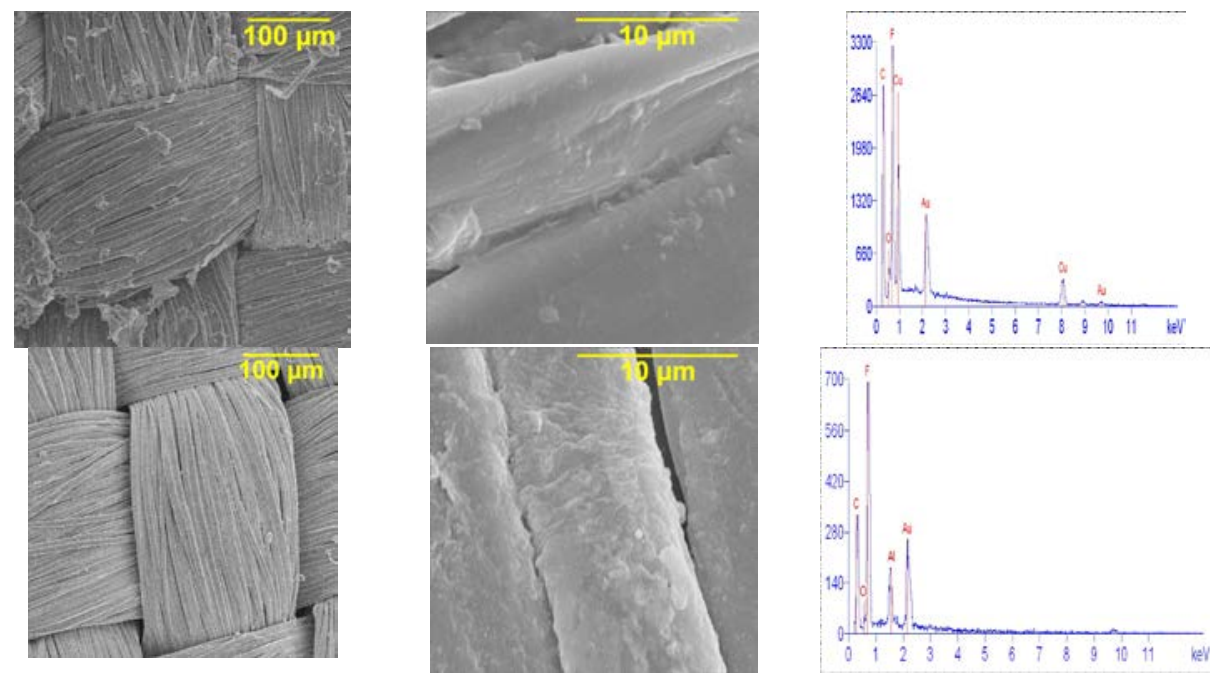

Рис. 3. Поверхность ткани фторлон-4 после нанесения Си и Al (снизу)

Выводы: разработана экранирующая одежда от ЭМИ, включающая средний промежуточный металлизированный слой на основе фторлона-4 и меди или алюминия. 


\section{Литература}

1. Технология полупроводниковых приборов и изделий микроэлектроники. Книга 6. Учеб. изд. Минайчев В.Е. Нанесение пленок в вакууме. М.: Высшая школа, 1989. - С. 108.

2. Колибабчук Д В.С., Скрипаченко К.К., Шумилин А.И., Таганова В.А., Пичхидзе С.Я. Блок термического нанесения металлов на фторполимеры. 4-ая международн. научн. конф. для молодых ученых, студентов и школьников. Наноматериалы и нанотехнологии: проблемы и перспективы. Саратов: СГТУ. 2015.- 3c.

3. Еленкова Т.В., Шумилин А.И., Таганова В.А., Пичхидзе С.Я. Усовершенствование установки термического нанесения металлов. Тольятти: ТГУ, 2015. - 3c.

4. Маслов А.А., Пичхидзе С.Я. Термическое нанесение алюминия на фторлон-4. Молодой ученый. №24.1 (104.1), Балаково: БИТИ НИЯУ МИФИ, 2015. - с.68-71. 